\title{
Pseudoretinitis pigmentosa due to syphilis: a case report and literature review
}

\author{
Pseudorretinose pigmentária por sífilis: relato de caso e revisão de literatura

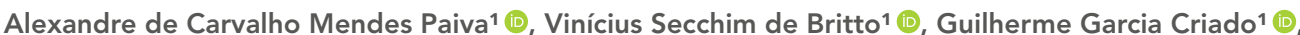 \\ Kelma Macedo Pohlmann Simões ${ }^{2}$ (i), Mário Martins dos Santos Motta ${ }^{3}$ (i)
}

${ }_{1}^{1}$ Medical Residency Program in Ophthalmology, Department of Ophthalmology, Universidade Federal do Estado do Rio de Janeiro, Hospital Universitário Gaffrée e Guinle, Rio de Janeiro, RJ, Brazil. 2 Department of Ophthalmology, Hospital Universitário Gaffrée e Guinle, Universidade Federal do Estado do Rio de Janeiro, Rio de Janeiro, RJ, Brazil Hospital Universitário Gaffrée e Guinle, Universidade Federal do Estado do Rio, Rio de Janeiro, RJ, Brazil.

\section{Paiva AC, Britto VS, Criado GG, Simões KM, Motta MM. Pseudoretinitis pigmentosa due to syphilis: a case report and literature review. Rev Bras Oftalmol. 2021:80(4):e0025.}

Keywords:

Syphilis; Neurosyphilis; Uveitis, posterior; Night blindness;

Retinitis pigmentosa

Descritores:

Sífilis; Neurossífilis; Uveíte posterior; Cegueira noturna; Retinose pigmentar

Received on: Mar 18, 2021

Accepted on: Apr 23, 2021

Corresponding author: Alexandre de Carvalho Mendes Paiva Rua Mariz e Barros, 775 - Tijuca Zip code: 20270-001 - Rio de Janeiro,

RJ, Brazil

E-mail: adcarvalho@hotmail.com

Institution: Hospital Universitário Gaffrée e Guinle, Universidade Federal do Estado do Rio, Rio de Janeiro, RJ, Brazil.

Conflict of interest: no conflict of interest.

Financial support: the authors received no financial support
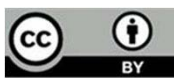

Copyright $@ 2021$

\section{ABSTRACT}

Syphilis is a sexually transmitted infection caused by the spirochete Treponema pallidum. Ocular involvement can occur at any time, and it may affect $10 \%$ of patients in the secondary stage, and from $2 \%$ to $5 \%$ in the tertiary stage. Uveitis is the most common presentation of ocular syphilis, affecting $0.4 \%$ to $8 \%$ of patients with systemic disease. Chorioretinitis is the most common posterior alteration. We present the case of a 53-year-old male patient, presenting with bilateral low visual acuity and nyctalopia for 3 years. His physical examination revealed decreased pupillary reflex, anterior vitreous cells, physiologic papillae, arteriolar attenuation, reduced foveal reflex, diffuse retinal pigment epithelium atrophy, peripapillary and perivascular punctate pigment accumulation and peripheral chorioretinitis. Full-field electroretinogram was extinct in both eyes. Treponemal syphilis test was positive. Previously diagnosed as retinitis pigmentosa, evolved to blindness, despite proper treatment. Our case shows syphilis as a significant cause of blindness. Atypical presentations of retinitis pigmentosa must warn ophthalmologists to etiologies of pseudoretinitis pigmentosa, such as syphilis.

\section{RESUMO}

A sífilis é uma infecção sexualmente transmissível causada pela espiroqueta Treponema pallidum. A sífilis ocular pode ocorrer em qualquer estágio da doença, chegando a 10\% na forma secundária e a $2 \%$ a $5 \%$ em sua forma terciária. A uveíte é a manifestação ocular mais comum, ocorrendo em 0,4\% a $8 \%$ dos pacientes com a doença sistêmica. A coriorretinite é a manifestação mais comum do segmento posterior. Apresentamos o caso de um paciente do sexo masculino, 53 anos, com queixa de baixa acuidade visual e nictalopia há 3 anos. Seu exame físico revelou lentificação dos reflexos pupilares, celularidade no vítreo anterior, papilas fisiológicas, atenuação arteriolar, redução do reflexo foveal, atrofia difusa do epitélio pigmentar da retina, acúmulo punctato de pigmento em regiões peripapilar e perivascular e coriorretinite periférica. Eletrorretinograma de campo total extinto em ambos os olhos. O teste treponêmico foi positivo. Foi previamente diagnosticado como portador de retinose pigmentar, evoluindo com cegueira, a despeito do tratamento correto instituído. Esse caso mostra a sífilis como importante causadora de cegueira. Casos atípicos de retinose pigmentar devem alertar o oftalmologista para causas de pseudorretinose pigmentar, como a sífilis. 


\section{INTRODUCTION}

Syphilis is a sexually transmitted infection, caused by the spirochete Treponema pallidum. Its natural history is commonly divided into four stages: primary, secondary, tertiary and latent. Ocular involvement can occur at any time, and affects $10 \%$ of patients in the secondary stage, and $2 \%$ to $5 \%$ in the tertiary stage. ${ }^{(1,2)}$ Any eye structure can be involved, including anterior segment, lens, uvea, retinal vasculature, optic nerve, cranial nerves and pupillomotor pathways. ${ }^{(1)}$

Syphilitic uveitis is the most common presentation of ocular syphilis, occurring in $0.4 \%$ to $8 \%$ of patients with systemic disease, ${ }^{(1,2)}$ and chorioretinitis is the most common posterior segment alteration. Retinitis, neuroretinitis, papillitis, retinal vasculitis, syphilitic posterior placoid chorioretinitis (SPPC) and panuveitis can also occur. ${ }^{(2,3)}$

We present a case initially diagnosed as retinitis pigmentosa (RP), which later was found to be latent syphilis.

\section{CASE REPORT}

A 53-year-old male patient with no relevant clinical and family history, presented with nyctalopia and progressive visual impairment in both eyes (OU) for the past three years. The onset of symptoms was one month after a facectomy, with intraocular lens implantation and no complications in OU. No ocular pain, hyperemia, photopsias and trauma reported. Snellen best corrected visual acuity (BCVA) was hands movement (HM) in OU, with no improvement in potential acuity tests. His anterior segment and dilated fundoscopic exam revealed reduced pupillary reflex, anterior vitreous cells, physiologic papillae, arteriolar attenuation, reduced foveal reflex, diffuse retinal pigment epithelium (RPE) atrophy, peripapillary, perivascular punctate pigment accumulation, and several peripheral chorioretinitis in OU (Figure 1A). Goldmann tonometry was $16 \mathrm{mmHg}$ in OU.

Full-field electroretinogram (ERG) was extinct in scotopic (Figure 2A) and photopic (Figure 2B) systems, and there were no reproducible waves or any $\mathrm{P} 100$ evidence in visually evoked potential in OU. SITA-Standard 24-2 automated perimetry was impractical in right eye (OD) and unreliable in left eye (OS). Macular spectral-domain optical coherence tomography (SDOCT) showed alterations in ellipsoid zone, absence of external limiting membrane in OU (Figures $3 \mathrm{~A}$ and $3 \mathrm{~B}$ ), and focal areas of choroidal punctate hyperreflectivity in OD (Figure 3A). In addition, central macular thickness was $231 \mathrm{~mm}$ in OD and 233 $\mathrm{mm}$ in OS. Fundus autofluorescence: central hypoautofluorescence (photoreceptor atrophy) surrounded by

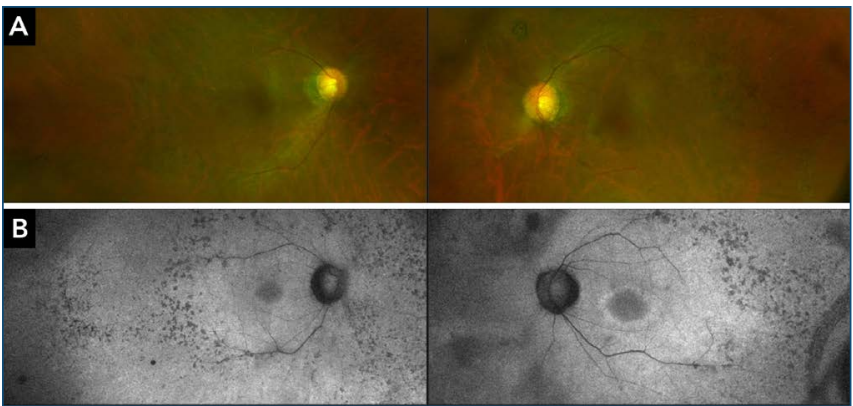

Figure 1. (A) Retinography: arteriolar attenuation, perivascular pigment and diffuse retinal pigment epithelium atrophy. (B) Fundus autofluorescence showing central hypoautofluorescence (photoreceptor atrophy) surrounded by a hyperautofluorescent ring (lipofuscin accumulation). Equatorial punctate hypoautofluorescence is also observed.

a hyperautofluorescent ring (lipofuscin accumulation) with peripapillary and equatorial points of hypoautofluorescence (pigment) in OU (Figure 1B). Wide-field fluorescein angiography, arteriovenous phase in OU: normal circulatory times, window defect hyperfluorescence lesions (RPE atrophy) interspersed with perivascular blockage (punctate pigmentation due to RPE hyperplasia) areas of hypofluorescence (Figure 4A). Late venous phase in OU: impregnation of main veins and macular branches (vasoocclusive phlebitis) (Figure 4B). Recirculation phase in OU: hyperfluorescent peripheric chorioretinitis (window defect due to RPE atrophy). Late papillary hyperfluorescence (leakage). Great area of temporal chorioretinitis in OS (Figure $4 C$ ). Tuberculin skin test and chest X-ray were unremarkable. Laboratory workup showed a negative VDRL test and a positive FTA-Abs immunoglobulin G (IgG) syphilis test.

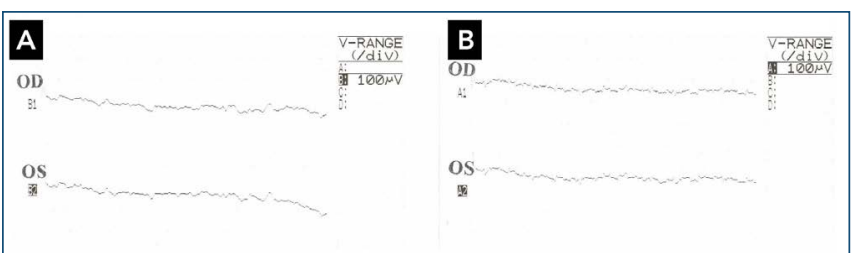

Figure 2. Full-field electroretinogram in both eyes: extinct pattern in scotopic (A) and photopic (B) systems. OD: right eye; OS: left eye.
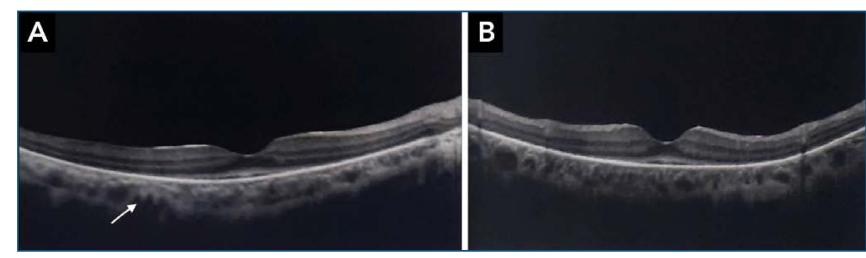

Figure 3. Pretreatment spectral domain optical coherence of the right eye (A) and left eye (B): changes in ellipsoid zone in both eyes and choroidal punctate hyperreflectivity (arrow) in right eye. 


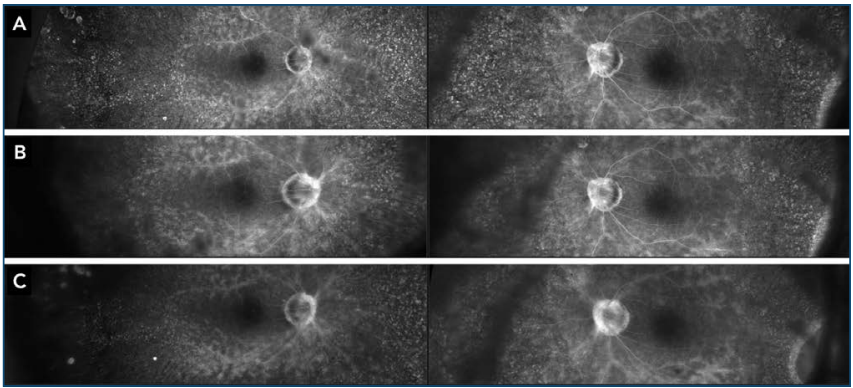

Figure 4. (A) Wide-field fluorescein angiography, arteriovenous phase in OU: window defect hyperfluorescence areas due to retinal pigment epithelium atrophy with equatorial punctate hypofluorescence (punctate pigmentation due to retinal pigment epithelium hyperplasia). (B) Fluorescein angiography, late venous phase in OU: discreet impregnation of main veins and macular branches (vasoocclusive phlebitis). (C) Fluorescein angiography, recirculation phase in OU: hyperfluorescent peripheral chorioretinitis (window defect due to retinal pigment epithelium atrophy). Late papillary hyperfluorescence (leakage). Great area of temporal chorioretinitis in left eye.

Upon diagnosis of syphilitic pseudoretinitis pigmentosa (pseudoRP), the patient was treated with ceftriaxone $2 \mathrm{~g}$ intravenous, for 14 days, with improvement of BCVA in OS (20/200). There were no alterations in pupillary reflex and fundus examination in OU. We performed a new macular SDOCT, which showed the same alterations in addition to epiretinal membrane (ERM) in OU (Figures 5A and $5 \mathrm{~B})$. There were no areas of punctate choroidal hyperreflectivity in OD (Figure 5A). Central macular thickness was $223 \mathrm{~mm}$ in OD and $233 \mathrm{~mm}$ in OS.
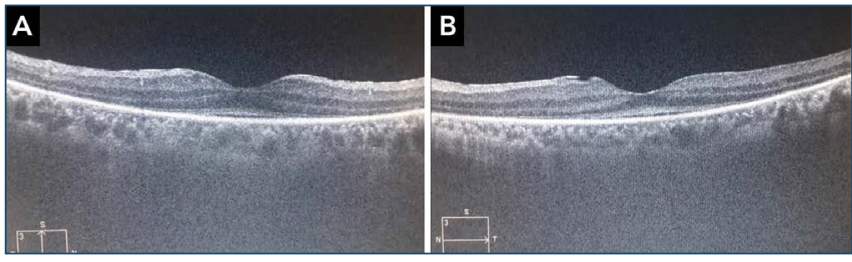

Figure 5. Post-treatment spectral domain optical coherence tomography of the OD (A) and OS (B) showing persistent alterations of the ellipsoid zone and of the external limiting membrane in $\mathrm{OU}$, extensive epiretinal membrane in $\mathrm{OU}$ and disappearance of choroidal hyperreflectivity in OD.

\section{DISCUSSION}

Retinitis pigmentosa is a group of inherited retinal degeneration diseases resulting from photoreceptor cell death. ${ }^{(4)}$ Nyctalopia typically precedes visual impairment. Fundus appearance includes pigmentary deposits resembling bone spicule, initially in peripheral retina, narrowing of retinal vasculature, waxy pallor of papilla, and various degrees of retinal atrophy. ${ }^{(5)}$ Posterior subcapsular cataract, vitreous cells, ERM and cystoid macular edema can also occur. ${ }^{(4,5)}$ Several entities resemble RP, leading to a pseudoRP, such as paraneoplastic syndromes, trauma, chronic retinal detachment, retinal photocoagulation, and infections like rubella and syphilis. ${ }^{(5)}$

Syphilitic pseudoRP is a chronic posterior uveitis that usually occurs in latent stages of the disease. Without effective therapy, bacteria spread through the retina causing different degrees of chorioretinitis, vitreous haze and finally pseudoRP. ${ }^{(2)}$

The key points to make diagnosis of syphilitic pseudoRP include no family history of RP; atypical visual fields; depressed ERG, whether or not it is extinct; severe visual impairment at first clinical consultation; late and/or sudden onset of RP; retinal inflammation; and positive specific treponemal tests associated to negative non-treponemal tests. ${ }^{(4,6)}$

RP typically evolves through decades. ${ }^{(5)}$ Despite being an important cause of blindness, patients usually have a relative degree of central visual preservation at first clinical appointment. ${ }^{(7)}$ The onset of symptoms of our patient was at the age of 50 years, after facectomy in OU, with legal blindness at his first consultation in our service. In addition, he denied family history of ocular degenerative diseases and blindness.

Ocular inflammation is a valuable clue of pseudoRP. (6) Our patient showed vitreous cells on biomicroscopy. On fluorescein angiography, some inflammatory signs, such as window defect hyperfluorescence lesions interspersed with perivascular blockage areas of hypofluorescence, and late hyperfluorescence due to papillary leakage were observed. In addition, vasoocclusive residual phlebitis could be seen.

Photoreceptor loss due to syphilis leads to lipofuscin abnormal accumulation (hyperautofluorescence), and RPE and retinal atrophy in hypoautofluorescent areas. ${ }^{(8)}$ Our patient showed a fundus autofluorescence pattern that enabled diagnosing syphilitic pseudoRP; that is, punctate equatorial hypoautofluorescence due to RPE hyperplasia, rather than in a bone spicule shape, characteristic of RP. ${ }^{(8,9)}$

In RP, ERG becomes extinct after many years of the disease. ${ }^{(5)}$ In syphilis pseudoRP, ERG changes correspond to the amount of retinal damage. ${ }^{(6)}$ Full-field ERG of the patient was extinct in OU, three years after onset of symptoms.

Spectral domain optical coherence tomography after treatment revealed ERM changes in ellipsoid zone, and no external limiting membrane. We believe these changes were responsible for the final low BCVA. Punctate choroidal hyperreflectivity, observed in the first spectral domain optical coherence tomography, disappeared after treatment. Such alteration has been described in eyes with SPPC, and usually disappears after antibiotic therapy. ${ }^{(3)}$ 
Intravenous penicillin $\mathrm{G}$ is the main treatment for ocular syphilis, but alternative treatment with ceftriaxone $2 \mathrm{~g}$ intravenously, for 14 days, can also be used..$^{(2,3,10)}$ Early diagnosis and therapy can still improve BCVA, as long as there has been no RPE and external photoreceptors damage. ${ }^{(2)}$ Ophthalmologists must be aware of negative VDRL tests and always order treponemal tests. ${ }^{(6)}$ Due to delayed diagnosis, our patient evolved with a BCVA of 20/200 in OS, maintaining BCVA of hands movement in OD. In conclusion, syphilis, the great masquerader, should always be considered in atypical RP.

\section{REFERENCES}

1. Klein A, Fischer N, Goldstein M, Shuman S, Habot-Wilner Z. The great imitator on the rise: ocular and optic nerve manifestations in patients with newly diagnosed syphilis. Acta Ophthalmol. 2019;97(4):e641-7.
2. Zhang X, Du Q, Ma F, Lu Y, Wang M, Li X. Characteristics of syphilitic uveitis in northern China. BMC Ophthalmol. 2017;17(1):95.

3. Pichi F, Ciardella AP, Cunningham Jr ET, Morara M, Veronese C, Jumper MJ, et al. Spectral Domain optical coherence tomography findings in patients with acute syphilitic posterior placoid chorioretinopathy. Retina. 2014;34(2):373-84.

4. Fujiwara K, Ikeda Y, Murakami Y, Tachibana T, Funatsu J, Koyanagi Y, et al. Assessment of Central Visual Function in patients with retinitis Pigmentosa. Sci Rep. 2018;8(1):8070.

5. Hamel C. Retinitis pigmentosa. Orphanet J Rare Dis. 2006;1:40.

6. Heckenlively JR. Secondary retinitis pigmentosa (syphilis). In: Lawwill T, editor. ERG, VER and psychophysics. Dordrecht: Springer; 1977. p.245-55.

7. Igarashi N, Matsuura M, Hashimoto $Y$, Hirasawa $K$, Murata H, Inoue $T$, et al. Assessing visual fields in patients with retinitis pigmentosa using a novel microperimeter with eye tracking: The MP-3. PLoS One. 2016;11(11):e0166666.

8. Jumper JM, Randhawa S. Imaging syphilitic uveitis. Int Ophthalmol Clin 2012;52(4):121-9

9. Yung $M$, Klufas MA, Sarraf D. Clinical applications of fundus autofluorescence in retinal disease. Int J Retin Vitr. 2016;2:12.

10. Macovei ML, Georgescu RD. Papillitis in neurosyphilis. Rom J Ophthalmol. 2019;63(4):406-11. 